$=0,67(p=0,009)$ và \%ChangeR5 có AUC = $0,783(p=0,000)$, \%ChangeFres có AUC = $0,785$ ( $p=0,000)$. Như vậy, chúng tôi thu được kết quả các chỉ số IOS là R5Pre, \%ChangeR5, AXPre, \%ChangeFres có giá trị trong gợi ý chẩn đoán HPQ ở mức độ trung bình với điểm cắt lân lượt là $0,88 \mathrm{kPa} / \mathrm{L} / \mathrm{s} ; 18 \% ; 3,38 \mathrm{kPa} / \mathrm{L}$ và $15,5 \%$.

Có những sư khác biệt giữa các nghiên cứu trên có thể do nhóm đối tượng của từng nghiên cứu có độ tuổi, chủng tộc, môi trường sống khác nhau; bên cạnh đó, các giá trị tham chiếu sử dụng làm chuẩn trong IOS chưa có giá trị riêng cho con người Việt Nam, dẫn đến những khác biệt.

\section{KẾT LUÂNN}

HPQ là bệnh lý hô hấp mạn tính thường gặp ở trẻ em. Tỷ lệ HPQ ở trẻ em nam cao hơn trẻ em nữ. Các triệu chứng lâm sàng thường gặp ở trẻ HPQ là ho, khò khè, khó thở, tức nặng ngực, các triệu chứng tái diễn nhiều lần, có yếu tố khởi phát và thường ít phát hiện triệu chứng thực thể khi khám lâm sàng. Có sự phù hợp ở mức độ trung bình giữa chẩn đoán $\mathrm{HPQ}$ theo GINA và quyết định 4888 của Bộ Y tế (QĐ4888) với gợi ý chẩn đoán dựa vào nghiệm pháp hôi phục phế quản (test HPPQ) trong IOS (kappa = 0.432). Giá trị R5, AX trước nghiệm pháp HPPQ, sự thay đổi R5, Fres sau test HPPQ là các chỉ số có giá trị gợi ý chẩn đoán HPQ ở trẻ em. R5Pre có AUC = $0,66$ ( $p=0,015)$, AXPre có $A U C=0,67$ ( $p=$ $0,009)$ và \%ChangeR5 có $A U C=0,783(p=$ $0,000)$, \%ChangeFres có $A U C=0,785$ ( $p=$
0,000 ) có giá trị trong gợi ý chẩn đoán HPQ ở mức độ trung bình với điểm cắt lân lượt là 0,88 $\mathrm{kPa} / \mathrm{L} / \mathrm{s} ; 3,38 \mathrm{kPa} / \mathrm{L} ; 18 \%$ và $15,5 \%$.

\section{TÀI LIÊU THAM KHẢO}

1. Bộ Y tế (2016), Quyết định số 4888/QĐ-BYT "Hướng dấn chân đoán và điều trị hen trẻ em dưới 5 tuổi".

2. Marotta A., Klinnert M.D., Price M.R. et al (2003), "Impulse oscillometry provides an effective measure of lung dysfunction in 4-year-old children at risk for persistent asthma", J Allergy Clin Immunol, 112(2), 317-322.

3. Beydon N., Davis S.D. and Lombardi E (2007), "An Official American Thoracic Society/European Respiratory Society Statement: Pulmonary Function Testing in Preschool Children", Am J Respir Crit Care Med, 175(12), 1304-1345.

4. Oliveira Jorge P.P., de Lima J.H.P. and Chong E Silva D.C (2019), "Impulse oscillometry in the assessment of children's lung function", Allergol Immunopathol, 47(3), 295-302.

5. Song T.W., Kim K.W. and Kim E.S. et al (2008), "Utility of impulse oscillometry in young children with asthma", Pediatr Allergy Immunol, 19(8), 763-768.

6. Choi B.S., Kim K.W. and Lee Y.J. et al (2011), "Exhaled Nitric Oxide is Associated with Allergic Inflammation in Children", J Korean Med Sci, 26(10), 1265-1269.

7. Diêp Thắng, Đăng Huỳnh Anh Thư và Nguyễn Phúc Hâau (2013), "Giá trị dao động xung ký trong chẩn đoán hen phế quản", Y Học TP Hồ Chí Minh, 17(1), 256-259.

8. Burke W., Fesinmeyer M. and Reed K (2003), "Family history as a predictor of asthma risk", Am J Prev Med, 24(2),160-169.

\title{
THỰC TRANG SÂU CHÂN RĂNG Ở NGƯỜI CAO TUỔI TẠI BÊ̂NH VIỆN RĂNG HÀM MẠTT TRUNG ƯƠNG HÀ NộI NĂM 2020 - 2021
}

\section{TÓM TẮT}

Mục tiêu: Mô tả thực trạng sâu chân răng ở người cao tuổi tại bệnh viện Răng hàm mặt Trung ương Hà Nội năm 2020 - 2021. Đối tượng và phương pháp nghiên cứu: mô tả cắt ngang 192 bệnh nhân người cao tuổi đến khám tại Khoa Điều trị răng miệng người cao tuổi. Tiêu chuẩn lựa chọn là những bệnh nhân

*Bệnh viện E Hà Nọi

**Bệnh viện Răng Hàm Mặt TW HN; Viện đào tạo

Răng Hàm Mặt, Đại học Y Hà Nội

Chiu trách nhiệm chính: Hà Lan Hương

Email: lanhuongrhm0915@gmail.com

Ngày nhận bài: 15.3.2021

Ngày phản biện khoa học: 7.5.2021

Ngày duyệt bài: 13.5.2021

\section{Hà Lan Hương*, Trần Cao Bính**}

trên 60 tuổi đến khám tại khoa và đồng ý tham gia vào nghiên cứu. Tiêu chuẩn loại trừ là những bệnh nhân mắc bệnh toàn thân và tại chố cấp tính, mất răng toàn bộ và không đủ khả năng trả lời phỏng vấn. Kết quả: có 192 bệnh nhân người cao tuổi (87 nam, 105 nữ) đã được khám và đánh giá tình trạng sâu chân răng. Số bênh nhân có ít nhất một tổn thương sâu chân răng là $51(26,6 \%)$, trong đó có số bệnh nhân nam là $21(41,2 \%)$, số bệnh nhân nữ là 30 ( $58,8 \%)$, sự khác biệt này không có ý nghĩa thống kê $(p=0,155>0,05)$. Tỉ lệ răng tụt lợi là $75 \%$. Chỉ số RCI là 1,3 trong đó nhìn chung chỉ số RCI của các răng thuộc cung răng hàm dưới cao hơn các răng thuộc cung răng hàm trên. Tốn thương sâu chân răng hay gặp nhất ở nhóm răng cửa và răng hàm lớn hàm dưới. Về sự phân bố tổn thương sâu chân theo các mặt cho thấy hay gặp nhất ở mặt bên và ít gặp nhất ở mặt trong chân răng. Kết luận: Tỉ lệ sâu chân răng 
trên bệnh nhân người cao tuổi ở mức trung bình, trong đớ tỉ lệ sâu chân răng ở bệnh nhân nữ cao hơn ở bệnh nhân nam. Thực trang mất răng, sâu chân răng, tụt lợi của các vị trí răng tương đối cân xứng qua đường giữa. Nhóm răng cửa và răng hàm lớn hàm dưới là những răng hay gặp tổn thương sâu chân răng nhất. Nhóm răng hàm nhỏ và răng hàm lớn thứ 3 là những răng hiếm gặp tình trạng sâu chân răng. Mặt bên chân răng là bề mặt xuất hiện tổn thương sâu chân răng nhiều nhất.

Tứ khóa: sâu chân răng, người cao tuổi, RCI, tụt lợi.

\section{SUMMARY}

\section{THE SITUATION OF ROOT CARIES IN THE ELDERLY AT THE NATIONAL HOPSPITAL OF ODONTO-STOMATOLOGY, HANOI IN 2020 - 2021}

Aim: Describe the current situation of root caries in the elderly at the National of Hospital OdontoStomatology, Hanoi in 2020 - 2021. Subjects and methods: Our research included 192 elderly patients who came to the Department of Dental Treatment for the Elderly - National Hospital of Odonto-Stomatology, Hanoi. We conducted cross-sectional description study. Selection criteria were patients aged 60 years old and above and agreed to participate in our research. Exclusion criteria were patients who had acute diseases, were edentulous or unable to answer interviews. Results: A total of 192 elderly patients (87 men, 105 women) were examined and assessed for the state of root caries. The number of patients with at least one root caries lesion was 51 patients, accounting for $26.6 \%$, of which the number of males was $21(41.2 \%)$ and the figure for females was 30 $(58.8 \%)$, this difference is not statistically significant $(p=0.155>0.05)$. The rate of recession is $75 \%$. The RCI index is 1.3, in which, in general, the RCI of the teeth in the lower arch is higher than that of the teeth in the maxillary arch. Root caries lesions are most common in the incisors and mandibular molars. In relation to the dental surfaces, it was found that the number of root caries in the lateral surfaces is the highest and the figure for lingual surface is the lowest. Conclusions: The rate of dental caries in elderly patients is average, in which the rate of root caries in females is higher than in males. The reality of tooth loss, tooth decay, and receding gums of the tooth positions are relatively symmetrical across the midline. Decayed roots were most frequently observed for incisors and mandibular molars. The group of premolars and the third molars are rarely affected by root caries The lateral surfaces experiences the highest rates of root caries.

Key words; root caries, elderly, RCI, recession.

\section{I. ĐẶT VẤN ĐỀ}

Sâu chân răng được định nghĩa là tổn thương sâu ở phía dưới đường ranh giới men-cement, không bao gồm tổn thương men răng gần kề. Sâu chân răng thường xuất hiện ở những bề mặt chân răng bị bộc lộ, tuy nhiên cũng có những nghiên cứu cho thây có $10-20 \%$ tổn thương sâu chân răng xuất hiện dưới lợi.

Trên thế giới, khá nhiều nghiên cứu về tình trạng sâu chân răng đã được tiến hành. Pentapati và cộng sự tiến hành nghiên cứu tổng quan thông qua 74 bài báo được công bố trên toàn thế giới và kết quả cho thấy tỷ lệ sâu chân răng là $41,5 \%$ [5]. Ở Trung Quốc (2018), tỉ lệ sâu chân răng theo điêuu tra sức khỏe răng miệng toàn quốc là $61,9 \%$. Ở Việt Nam, theo điêu tra sức khỏe răng miệng toàn quốc năm 2019, tỷ lệ sâu chân răng của người trên 65 tuổi là 37,2\% [1].

Nếu không được điều trị kịp thời, bệnh sâu chân răng được cho là một những yếu tố nguy cơ chính dẫn đến tình trạng mất răng ở người già. Điều này đã gây ra những ảnh hưởng nghiêm trọng đến chất lượng cuộc sống của người cao tuổi.

Trong những năm gần đây, cơ cấu dân số của Việt Nam có sự thay đổi rõ rệt, tỉ lệ người cao tuổi tăng nhanh. Do đó, việc chăm sóc sức khỏe nói chung và chăm sóc sức khỏe răng miệng nói riêng đang trở thành vấn đề ưu tiên. Sâu chân răng là bệnh có thể dự phòng được, do đó việc hiểu biết rõ về thực trạng, các yếu tố nguy cơ và yếu tố bảo vệ giúp cho chúng ta có thể đưa ra những biện pháp dự phòng và điều trị hiệu quả hơn. Chúng tôi muốn tiến hành nghiên cứu với mục tiêu. Mô tả thực trạng sâu chân răng ở người cao tuổi tại bệnh viện Răng hàm mặt Trung ương Hà Nội năm 2020 - 2021.

\section{II. ĐỐl TƯƠNGG VÀ PHƯƠNG PHÁP NGHIÊN CỨU}

Đối tượng nghiên cứu: là những bệnh nhân người cao tuổi đến khám tại Khoa Điều trị răng miệng người cao tuổi -bệnh viện Răng Hàm Mặt Trung ương Hà Nội.

Tiêu chuẩn lựa chọn: Bệnh nhân trên 60 tuổi đến khám tại Khoa điều trị răng miệng người cao tuổi - bệnh viện Răng hàm mặt Trung ương Hà Nội. Có sự đồng ý và tự nguyện tham gia vào nghiên cứu.

Tiêu chuẩn loại trừ: Bệnh nhân có các bệnh toàn thân hoặc răng miệng cấp tính.

Bệnh nhân mất răng toàn bộ.

Bệnh nhân không đủ khả năng trả lời khi phỏng vấn

Phương pháp nghiên cứu: mô tả cắt ngang

Cỡ mẫu. Sử dụng công thức ước lượng một tỉ lệ trong nghiên cứu cắt ngang mô tả:

$$
N=\frac{Z^{2}(1-a / 2) p(1-p)}{d^{2}}
$$

Trong đó: ( $\mathrm{n}$ : cõ̃ mẫu tối thiểu cần nghiên cứu; $\mathrm{p}=0,372$ theo điều trị sức khỏe răng 
miệng toàn quốc năm 2019 [2]; d: độ chính xác mong muốn, chọn $d=0,07 ; a=0.05$ ).

Thay các tham số trên vào công thức tính được cỡ mẫu là $\mathrm{n}=192$.

\section{Các bước tiến hành nghiên cứu:}

- Phỏng vấn trực tiếp: Phỏng vấn đối tượng nghiên cứu để thu thập các thông tin cá nhân (tuổi, giới, trình độ học vấn, nghề nghiệp trước khi về hưu, tiền sử bênh toàn thân, thói quen vê sinh răng miệng, có sử dụng thuốc lá...).

- Khám lâm sàng: xác định thực trạng bệnh sâu chân người cao tuổi và một số bệnh lý liên quan.

Đánh giá tổn thương sâu chân răng dựa theo hệ thống đánh giá ICCMS (International caries classification and management system)

- Mỗi răng được tiến hành khám trên tất cả các mặt răng (gần, xa, ngoài, trong)

- NR: bề mặt răng không bị tụt lợi.

- Bề mặt chân răng tụt lợi khi nhìn thấy ranh giới men - cement.

- Thổi khô bề mặt chân răng trong $5 s$

- Nếu bề mặt chân răng không đổi màu: Không có tổn thương sâu chân răng.

- Nếu bề mặt chân răng đổi màu so với mô răng xung quanh: có tổn thương sâu chân răng.
Đánh giá độ sâu tổn thương SCR

- Nếu tổn thương < 0,5mm: chưa hình thành lỗ sâu.

- Nếu tổn thương >0,5mm: đã hình thành lỗ sâu

- Nếu tổn thương gồ ghề, đục, mềm hoặc dai: tổn thương SCR hoạt động

- Nếu tổn thương nhẵn, bóng, cứng: SCR ngừng tiến triển

- Chỉ số RCI (root caries index

$\mathrm{RCI}=[(\mathrm{R}-\mathrm{D})+(\mathrm{R}-\mathrm{F})] /[(\mathrm{R}-\mathrm{D})+(\mathrm{R}-\mathrm{F})+(\mathrm{R}-\mathrm{N})] \times 100$

Trong đó: R-D là bề mặt chân răng tụt lợi có sâu chân răng; R-F: là bề mă̆t chân răng tụt lợi đẫ được hàn; R-N: là bề mặt chân răng tụt lợi lành mạnh.

Xử ií số liệu: số liệu được làm sạch, mã hóa và nhập bằng phần mềm Excel. Phẩn tích bằng phần mềm SPSS 16.0

\section{KẾT QUẢ NGHIÊN CỨU}

Tổng số có 192 bệnh nhân người cao tuổi (87 nam, 105 nữ) đã được khám và đánh giá tình trạng sâu chân răng. Số bệnh nhân có ít nhất một tổn thương sâu chân rẳng là 51 bệnh nhân chiếm $26,6 \%$, trong đó có số bệnh nhân nam là $21(41,2 \%)$, số bệnh nhân nữ là 30 (58,8\%).

Bảng 1: Sốlượng răng có tổn thương sâu chân răng, tụt lợi phân bố theo giới và nhóm tuổi.

\begin{tabular}{|c|c|c|c|c|c|}
\hline \multicolumn{2}{|c|}{ Số lượng răng SCR } & $\mathbf{N}$ & Trung bình công & Trung bình hang & p \\
\hline \multirow{4}{*}{ Nam } & $60-70$ & 53 & 0.75 & 88.77 & \multirow{8}{*}{0,155} \\
\hline & $71-80$ & 23 & 0.22 & 105.48 & \\
\hline & $81-90$ & 9 & 0.89 & 102.94 & \\
\hline & $>90$ & 2 & 2.50 & 71.00 & \\
\hline \multirow{4}{*}{ Nũ̃ } & $60-70$ & 69 & 0.58 & 91.86 & \\
\hline & $71-80$ & 25 & 0.68 & 105.20 & \\
\hline & $81-90$ & 10 & 1.50 & 119.75 & \\
\hline & $>90$ & 1 & 0.00 & 162.50 & \\
\hline \multicolumn{6}{|c|}{ Số lượng răng tụt lợi } \\
\hline \multirow{4}{*}{ Nam } & $60-70$ & 53 & 21.28 & 113.11 & \multirow{8}{*}{0,001} \\
\hline & $71-80$ & 23 & 18.65 & 82.26 & \\
\hline & $81-90$ & 9 & 15.44 & 48.67 & \\
\hline & $>90$ & 2 & 11.50 & 22.75 & \\
\hline \multirow{4}{*}{ Nữ } & $60-70$ & 69 & 20.55 & 104.42 & \\
\hline & $71-80$ & 25 & 19.44 & 93.78 & \\
\hline & $81-90$ & 10 & 16.00 & 51.20 & \\
\hline & $>90$ & 1 & 21.00 & 96.00 & \\
\hline
\end{tabular}

Nhận xét: Về số lượng răng có tốn thương sâu chân răng, nhóm bệnh nhân nam trên 90 tuổi có số trung bình cộng số lượng sâu chân răng cao nhất, trong khi đó nhóm bệnh nhân nữ có số trung bình cônng số lượng sâu chân răng cao nhất có độ tuổi từ 81-90 tuổi. Có sự khác biệt về số lượng răng có tổn thương sâu chân răng giữa các nhóm tuổi và giới, tuy nhiên sự khác biệt này không có ý nghĩa thống kê

\section{$(\mathrm{p}=0,155>0,05)$.}

Về số lượng răng tụt lợi, cả hai nhóm bệnh nhân nam và nữ từ 60-70 tuổi có trung bình hạng cao nhất. Nhóm bệnh nhân nam trên 90 và nhóm bệnh nhân nữ từ 81-90 tuổi có trung bình hạng thấp nhất. Có sự khác biệt về số lượng răng tụt lợi giữa các nhóm tuổi và giới, sự khác biệt có ý nghĩa thống kê $(p=0,001<0,05)$. 


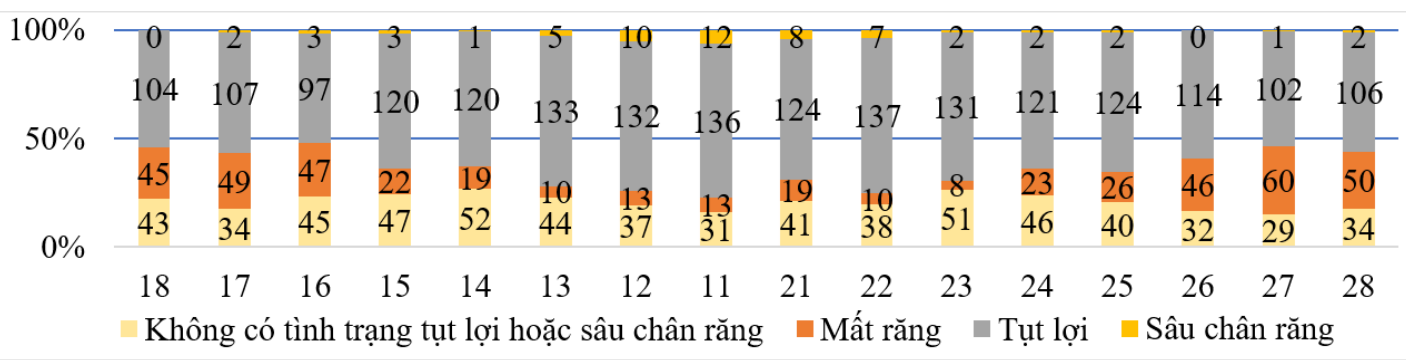

Biểu đồ 1: Tình trạng mất răng, tụt lợi, sâu chân răng hàm trên

Nhận xét. Tổn thương sâu chẩn răng và tình tràng tụt lợi hay gặp nhất ở nhóm răng cửa hàm trên và ít gặp ở răng nanh và răng hàm lớn hàm trên. Trong khi đó số lượng răng mất ở nhóm răng hàm hàm trên là cao nhất và ở nhóm răng cửa hàm trên là thấp nhất.

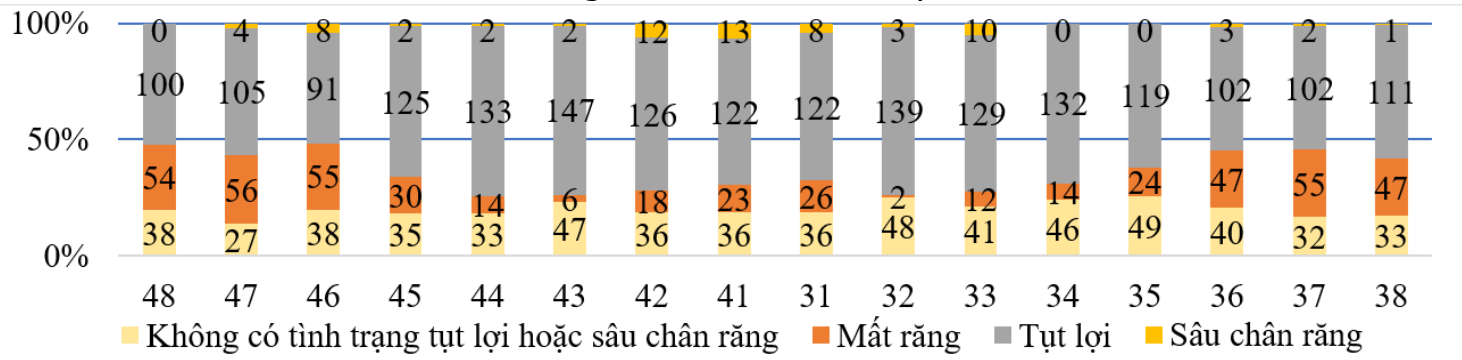

Biểu đồ 2: Tình trạng mât răng, tụt lợi, sâu chân răng hàm dưới

Nhận xét: dựa vào hai biểu đổ ta thấy, thực trạng mất răng, sâu chân răng, tựt lợi của các vị trí răng tương đối cân xứng qua đường giữa. Các vị trí răng có tỳ lệ không ghi nhận có tình trạng sâu răng, tưt lợi tương đối thấp nhưng khá đồng đều. Điều này cũng tương ứng với sự đồng đều của tổng số răng sâu chân răng, tụt lợi và mất giữa các vị trí răng. Đây là gợi ý để xây dựng mục tiêu làm rõ hơn các vấn đề liên quan giữa thực trạng sâu chân răng, tụt lợi và mất răng

Bảng 2: Số lượng răng hiện có và chỉ số RCI cho từng răng trên cung hàm

\begin{tabular}{|c|c|c|c|c|c|c|c|}
\hline Răng & Số răng & $\mathbf{\%}$ & $\mathbf{R C I}(\mathbf{\%})$ & $\mathbf{R a ̆ n g}$ & Số răng & $\mathbf{\%}$ & RCI (\%) \\
\hline $\mathbf{1 8}$ & 147 & 76.56 & 0.00 & $\mathbf{3 8}$ & 144 & 75.00 & 0.52 \\
\hline $\mathbf{1 7}$ & 141 & 73.44 & 0.88 & $\mathbf{3 7}$ & 135 & 70.31 & 0.74 \\
\hline $\mathbf{1 6}$ & 142 & 73.96 & 1.22 & $\mathbf{3 6}$ & 142 & 73.96 & 1.05 \\
\hline $\mathbf{1 5}$ & 167 & 86.98 & 0.89 & $\mathbf{3 5}$ & 168 & 87.50 & 0.00 \\
\hline $\mathbf{1 4}$ & 172 & 89.58 & 0.29 & $\mathbf{3 4}$ & 178 & 92.71 & 0.00 \\
\hline $\mathbf{1 3}$ & 177 & 92.19 & 1.25 & $\mathbf{3 3}$ & 187 & 97.40 & 0.66 \\
\hline $\mathbf{1 2}$ & 169 & 88.02 & 2.58 & $\mathbf{3 2}$ & 170 & 88.54 & 2.71 \\
\hline $\mathbf{1 1}$ & 167 & 86.98 & 2.87 & $\mathbf{3 1}$ & 158 & 82.29 & 2.79 \\
\hline $\mathbf{2 1}$ & 165 & 85.94 & 1.62 & $\mathbf{4 1}$ & 156 & 81.25 & 4.16 \\
\hline $\mathbf{2 2}$ & 175 & 91.15 & 1.53 & $\mathbf{4 2}$ & 162 & 84.38 & 3.26 \\
\hline $\mathbf{2 3}$ & 182 & 94.79 & 0.41 & $\mathbf{4 3}$ & 184 & 95.83 & 0.40 \\
\hline $\mathbf{2 4}$ & 167 & 86.98 & 0.60 & $\mathbf{4 4}$ & 176 & 91.67 & 0.56 \\
\hline $\mathbf{2 5}$ & 164 & 85.42 & 0.61 & $\mathbf{4 5}$ & 160 & 83.33 & 0.62 \\
\hline $\mathbf{2 6}$ & 146 & 76.04 & 0.00 & $\mathbf{4 6}$ & 129 & 67.19 & 3.20 \\
\hline $\mathbf{2 7}$ & 131 & 68.23 & 0.38 & $\mathbf{4 7}$ & 132 & 68.75 & 1.68 \\
\hline $\mathbf{2 8}$ & 140 & 72.92 & 0.71 & $\mathbf{4 8}$ & 138 & 71.88 & 0.00 \\
\hline
\end{tabular}

Nhân xét: Nhìn chung chỉ số RCI của các răng thuộc cung răng hàm dưới cao hơn các răng thuộc cung răng hàm trên. Chỉ số RCI của nhóm răng cửa dưới là cao nhất $(2,71-4,16)$, tiếp sau đó là nhóm răng cửa trên $(1,53-2,87)$ và nhóm răng hàm lớn hàm dưới bên phải $(1,68$ $3,2)$. Chỉ số RCI thấp ở nhóm răng hàm nhỏ và răng hàm lớn thứ 3.
Hơn một nửa số tổn thương sâu chân răng $(56,2 \%)$ xuất hiện ở mặt gần hoặc mặt xa của chân răng. 34 tổn thương sâu chân răng $(26,2 \%)$ xuất hiện ở mặt ngoài, 22 tổn thương $(16,9 \%)$ xuất hiện mặt trong và chỉ có 1 tổn thương xuất hiện ở cả 3 mặt răng (mặt ngoài và mặt tiếp giáp). 


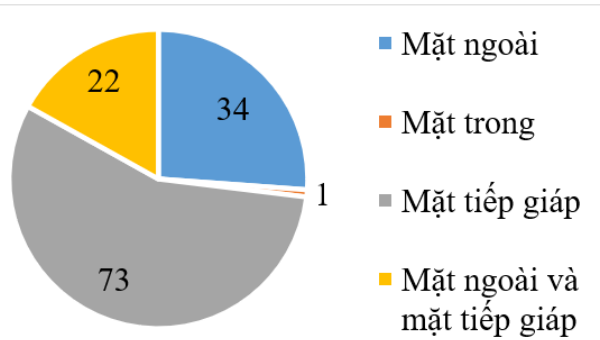

Biểu đồ 3: Mức độ hoạt động sâu chân răng

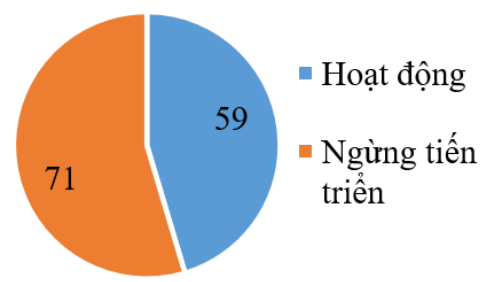

Biểu đồ 4: Phân bố vị trí tổn thương sâu chân răng

Nhận xét: Đối với mức độ hoạt động của các tổn thương sâu chân răng. Có 71 (54,6\%) tổn thương sâu chân răng ngừng tiến triển, 59 tổn thương $(45,4 \%)$ ở dạng hoạt động.

\section{BÀN LUÂN}

Kết quả nghiên cứu của chúng tôi cho thấy tỉ lệ sâu chân răng là $26,6 \%$, kết quả này tương tự với nghiên cứu tại Hong Kong năm 2020 của Zhang ] [8] và cộng sự (30\%). Tuy nhiên lại thấp hơn nhiều so với các nghiên cứu của Du và cộng sự 43,9\% [3], S.Imazato và cộng sự (53,3\%) [4] và Watanabe $(78,1 \%)$ [7]. Sự khác biệt này có thể do sự khác nhau về địa lý và chủng tộc.

Chỉ số sâu chân răng (RCI) thể hiện nguy cơ xuất hiện tổn thương sâu chân răng vì bề mặt chân răng bộc lộ và tiếp xúc trực tiếp với môi trường miêng. Chỉ số RCI trong nghiên cứu của chúng tôi là $1,3 \%$, kết quả này khá tương đồng với nhiên cứu tại Hong Kong của Zhang $\mathrm{J}$ và cộng sự $(0,7)$, [8]. Tuy nhiên theo một số nghiên cứu khác tại Úc chỉ số RCI lại khá cao, lần lượt là 38,7 [6].

Đối với từng răng, tác giả Du và cộng sự [3] cho kết quả răng hàm nhỏ và răng hàm là những răng hay gặp tổn thương sâu chân răng nhất. Trong khi đó theo nghiên cứu của tác giả $\mathrm{S}$. Imazato và cộng sự trên người cao tuổi ở Nhật Bản cho thấy răng nanh và răng hàm nhỏ là những răng có tỉ lệ sâu chân răng cao nhất [4]. Theo nghiên cứu của chúng tôi Khi phân tích chỉ số RCI theo từng răng, chỉ số RCI cao nhất được ghi nhận răng cửa giữa hàm dưới $(4,16)$, tiếp theo là răng hàm lớn thứ nhất hàm dưới bên phải $(3,2)$ và răng cửa giữa hàm trên $(2,87)$. Điều này có thể do liên quan đến tỉ lệ tụt lợi cao ở những răng nêu trên. Thêm vào đó việc chẩn đoán sâu chân răng bằng thăm khám lâm sàng có thể bỏ sót tổn thương, đặc biệt là những tổn thương sâu chân răng ở mặt bên của các răng

Rất nhiều nghiên cứu đã chỉ ra rằng tình trạng tụt lợi là yếu tố nguy cơ của sâu chân răng; theo nghiên cứu của chúng tôi tỉ lệ tụt lợi là $75 \%$, tương đồng với kết quả nghiên cứu của Bharateesh và Kokila $(80,1 \%)$ [2]. Tuy nhiên cũng có những nghiên cứu tỉ lệ hơn 95\%.

Theo nghiên cứu của tác giả S.Imazato [5], số tổn thương sâu chân răng dạng ngừng tiến triển và đã được hàn chiếm ưu thế. Kết luân này tương tự như nghiên cứu của chúng tôi với $54,6 \%$ tổn thương sâu chân răng ngừng tiến triển.

Sư phân bố tổn thương sâu chân răng theo mặt răng, theo nghiên cứu của Watanabe và cộng sự [7] cho thấy tổn thương sâu chân răng hay gặp ở mặt bên của các răng hàm trên và mắt ngoài các răng hàm dưới. Trong khi đó kết quả nghiên cứu của chúng tôi cho thấy tổn thương sâu chân răng hay gặp nhất ở mặt bên và xuất hiện ít nhất ở mặt trong chân răng.

\section{KẾT LUÂNN}

Tỉ lệ sâu chân răng trên bệnh nhân người cao tuổi $26,6 \%$, trong đó tỉ lệ sâu chân răng ở bệnh nhân nữ (28,6\%) cao hơn ở bệnh nhân nam (24,1\%).

Thực trạng mất răng, sâu chân răng, tụt lợi của các vị trí răng tương đối cân xứng qua đường giữa. Tỉ lệ tụt lợi là $75 \%$

Nhóm răng cửa và răng hàm lớn hàm dưới bên phải là những răng hay gặp tổn thương sâu chân răng nhất (chỉ số RCI cho nhóm răng cửa là $1,53-4,16$ và nhóm răng hàm lớn hàm dưới bên phải là $1,68-3,2)$. Nhóm răng hàm nhỏ và răng hàm lớn thứ 3 là những răng hiếm gặp tình trạng sâu chân răng (chỉ số RCI từ $0-0,89$ )

Mặt bên chân răng là bề mă̆t xuất hiện tổn thương sâu chân răng nhiều nhất $(56,2 \%)$.

\section{TÀI LIÊU THAM KHẢO}

1. Trinh Đình Hải, Nguyễn Thị Hồng Minh, and Trẩn Cao Bính điêu tra sức khỏe răng miệng toàn quốc 2019, Nhà xuất bản Y Học.

2. Bharateesh J.V. and Kokila G. (2014). Association of Root Caries with Oral Habits in Older Individuals Attending a Rural Health Centre of a Dental Hospital in India. J Clin Diagn Res JCDR, 8(11), ZC80-ZC82.

3. Du M., Jiang H., Tai B., et al. (2009). Root caries patterns and risk factors of middle-aged and 
elderly people in China. Community Dent Oral Epidemiol, 37(3), 260-266

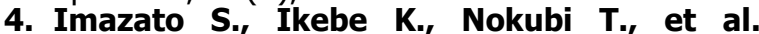
(2006). Prevalence of root caries in a selected population of older adults in Japan. J Oral Rehabil, 33(2), 137-143.

5. Pentapati K.C., Siddiq H., and Yeturu S.K. (2019). Global and regional estimates of the prevalence of root caries - Systematic review and meta-analysis. Saudi Dent J, 31(1), 3-15.
6. Silva M., Hopcraft M., and Morgan M. (2014), Dental caries in Victorian nursing homes. Aust Dent J, 59(3), 321-328

7. Watanabe M.G.C. (2003). Root caries prevalence in a group of Brazilian adult dental patients. Braz Dent J, 14(3), 153-156.

8. Zhang J., Leung K.C.M., Chu C.H., et al. (2020), Risk indicators for root caries in older adults using long-term social care facilities in Hong Kong. Community Dent Oral Epidemiol, 48(1), 14-20.

\section{ĐÁNH GIÁ TÁC DỤNG CHỐNG DỊ ỨNG THỰC NGHIỆM CỦA VIÊN NANG HỖ TRỢ ĐIỀU TRI ECZEMA}

\section{TÓM TẮT}

Mục tiêu: Đánh giá tác dung chống di ứng của viên nang hỗ trợ điều trị eczema trên chuột cống trắng. Đối tượng và phương pháp nghiên cứu: Viên nang hố trợ điều trị eczema được đánh giá tác dụng chống dị ứng trên mô hình động vật gây dị ứng thực nghiệm bằng compound 48/80. Đánh giá hiệu qưa thônng qua kiểm định sự khác biệt về chỉ số trung bình số lần gãi và gia tăng độ dày bàn chân của động vật thí nghiệm. Kết quả: ở cả 2 mức liều $0,6 \mathrm{~g} / \mathrm{kg} T T$ (tương đương lâm sàng) và $1,8 \mathrm{~g} / \mathrm{kg} T$ (gấp 3 lần liều tương đương lâm sàng), viên nang hố trợ điều trị eczema đều có tác dụng làm giảm số lần gãi của chuột và ức chế sự gia tăng chiều dày bàn chân chuột tai các thời điểm đánh giá có ý nghĩa thống kê $(p<0,05)$. Kết luận: Viên nang hố trợ điều trị eczema có tác dụng chống dị ứng trên mô hình thực nghiệm ở chuột cống trắng.

Tiư khóa: viên nang, hỗ trợ điều trị eczema, chống dị ứng, chống viêm.

\section{SUMMARY \\ STUDY ON EXPERIMENTAL ANTI-ALLERGIC EFFECT OF ANTI ECZEMA CAPSULES}

Objectives: To evaluate the anti-allergic effect of anti eczema capsules in rats. Subjects and methods: Anti eczema capsules (made from the vicous extracts of the traditional decotion, which includes: Caulis cum folium Lonicerae, Cortex Oroxyli, Flos Styphnolobii japonici imaturi, Fructus Xanthii strumarii, Folium Excoecariae, Cortex Phellodendri) were evaluated the antiallergic effect (anti itchines and acute inflammation) in model allergic rat caused by compound 48/80. Results: At the doses of $0.6 \mathrm{~g} / \mathrm{kgBW}$ (equivalent to the clinical dose) and $1.8 \mathrm{~g} / \mathrm{kgBW}$ (three time of clinical dose), anti eczema capsules showned that have good activities in anti

${ }^{1}$ Trường Đại học Dược Hà Nội

Chịu trách nhiệm chính: Nguyễn Mạnh Tuyển

Email: tuyennm@hup.edu.vn

Ngày nhận bài: 22.3.2021

Ngày phản biện khoa học: 10.5 .2021

Ngày duyệt bài: 24.5.2021

\section{Nguyễn Mạnh Tuyển', Phạm Thái Hà Văn ${ }^{1}$}

allergic by reduce the itchiness and imflamation action $(p<0,05)$. Conclusion: anti eczema capsules have antiallergic effect on experimental model rats.

Keywords: anti eczema capsule, anti allergic, anti imflamtion.

\section{I. ĐĂTT VẤN ĐỀ}

Bệnh eczema hay còn gọi là bệnh chàm là bệnh thường gặp nhất trong các bệnh da liễu, bểnh có thể gặp ở mọi lứa tuổi. Nguyên nhân gây bệnh eczema phức tạp nhưng bao giờ cũng có vai trò của "thể địa dị ứng". Bềnh thường kéo dài, dễ tái phát, khó điều trị, gây ảnh hưởng rất lớn đến chất lượng cuộc sống của người bệnh, đặc biệt là về thẩm mỹ. Việc điều trị eczema theo tầy y chủ yếu là điều trị triệu chứng bằng cách sử dụng corticoid bôi tại chỗ kết hợp với thuốc kháng histamin $\mathrm{H}_{1}$ và các vitamin dùng đường uống. Tuy nhiên kết quả điều trị thường không ổn định, thuốc gây nhiêu tác dụng không mong muốn, không thích hợp để điều trị kéo dài.

Sử dụng thuốc y học cổ truyền trong điều trị hỗ trợ điều trị chứng bệnh này là xu hướng lớn hiện nay. Bài thuốc hỗ trợ điều trị eczema gồm 6 vị thuốc kim ngân đằng (Caulis cum folium Lonicerae), hòe hoa (Flos Styphnolobii japonici imaturi), đơn lá đỏ (Folium Excoecariae), núc nác (Cortex Oroxyli), thương nhĩ tử (Fructus Xanthii strumarii), hoàng bá (Cortex Phellodendri) đã được sử dụng trên lâm sàng ở dạng thuốc thang cho hiệu quả điều trị tích cực. Trên cơ sở lý luận y dược học cổ truyền và các nghiên cứu về hoá học, tác dụng dược lý hiện đại, bài thuốc được cấu thành từ các nhóm thuốc: lương huyết (hòe hoa, đơn lá đỏ, thương nhĩ tử) kết hợp với các thuốc thanh nhiệt giải độc (núc nác, kim ngân đằng, hoàng bá), trừ thấp (núc nác, thương nhĩ tử, hoàng bá).

Trong các nghiên cứu trước đây, chúng tôi đã tiến hành bào chế cao đặc bài thuốc và đánh giá 